\title{
DE NUEVO SOBRE EL CONTROL JUDICIAL DE LA DISCRECIONALIDAD DE LA ADMINISTRACIÓN. \\ AL HILO DE LA INFRACCIÓN EN EL EJERCICIO DE LA JURISDICCIÓN COMO FUNDAMENTO DEL RECURSO DE CASACIÓN
}

\author{
OMAR BOUAZZA ARIÑO' \\ Universidad Complutense de Madrid \\ obouazza@der.ucm.es
}

Cómo citar/Citation

Bovazza Ariño, O. (2017).

De nuevo sobre el control judicial de la discrecionalidad de la Administración. Al hilo de la infracción en el ejercicio de la jurisdicción como fundamento del recurso de casación. Revista de Administración Pública, 202, 169-203. doi: https://doi.org/10.18042/cepc/rap.202.06

\section{Resumen}

El objeto de este trabajo consiste en el análisis de la infracción en el ejercicio de la jurisdicción como fundamento del recurso de casación. Se analizan los distintos supuestos planteados en la jurisprudencia del Tribunal Supremo y su contraste con los artículos 106 de la Constitución y 71.2 de la Ley de la Jurisdicción ContenciosoAdministrativa, en cuanto al poder de los tribunales de anular y, en su caso, sustituir las decisiones de la Administración.

\footnotetext{
Profesor titular de Derecho Administrativo. Este trabajo ha sido realizado en el marco del proyecto de investigación «El reto de la reafirmación del Estado del Bienestar en la protección de los derechos humanos», DER2015-65524-R (Ministerio de Economía y Competitividad/FEDER, UE).
} 


\section{Palabras clave}

Discrecionalidad administrativa; tutela judicial; jurisdicción; abuso; recurso de casación.

\section{Abstract}

The aim of this paper is to analyze the infringement in the exercise of jurisdiction as the basis of the cassation appeal through the different assumptions raised by the Supreme Court case-law and its contrast with articles 106 of the Spanish Constitution and 71.2 of the Spanish Administrative Jurisdiction Act, as to the power of the courts to annul and, where appropriate, to replace the decisions of the Public Administration.

\section{Keywords}

Administrative discretion; judicial protection; jurisdiction; abuse; cassation appeal. 


\section{SUMARIO}

I. APROXIMACIÓN AL TEMA: EL ARTÍCULO 71.2 LJCA Y SU INTERPRETACIÓN LITERAL. II. ITER PARLAMENTARIO DEL ARTÍCULO 71.2 LJCA. III. JURISPRUDENCIA DEL TRIBUNAL SUPREMO: 1. El Tribunal no incurre en infracción en el ejercicio de la jurisdicción si conoce de un asunto sobre el que tiene jurisdicción. 2. El tribunal no puede sustituir la decisión de la Administración cuando son posibles varias alternativas. 3. ¿Puede el tribunal sustituir la decisión de la Administración cuando solo es posible una alternativa? 4. El tribunal podrá corregir la decisión de la Administración cuando no se haya realizado correctamente la subsunción de los hechos en el supuesto de la norma. 5. La anulación judicial de una alternativa que obliga a la Administración a optar por la restante no implicará una infracción de las normas de jurisdicción. 6. ¿̇Puede el tribunal anular una disposición con la indicación de que revive la disposición preexistente? 7 . Autonomía local y sustitución judicial de la discrecionalidad administrativa. 8. ¿2Puede el tribunal controlar las omisiones reglamentarias? 9. El artículo 71.2 es aplicable —también- en ejecución de sentencia. IV. FINAL.

\section{APROXIMACIÓN AL TEMA: EL ARTÍCULO 71.2 LJCA Y SU INTERPRETACIÓN LITERAL}

El objeto de este trabajo consiste en el estudio de la jurisprudencia reciente del Tribunal Supremo sobre el ámbito y límites del poder de sustitución judicial de las determinaciones discrecionales de las decisiones de la Administración que anula y la medida en la que dicha sustitución puede fundamentar un recurso de casación por infracción (abuso o exceso) de jurisdicción. No se trata de cuestionar el poder del juez de anular una decisión administrativa discrecional, como queda claramente resuelto en la Constitución española de 1978, sino de comprobar si, una vez anulada, es posible su sustitución por la opción u opciones restantes que puedan concurrir. Debemos recordar sin falta el artículo 106 de la Constitución, que dispone que: «Los Tribunales controlan la potestad reglamentaria y la legalidad de la actuación administrativa, así 
como el sometimiento de ésta a los fines que la justifican», precepto clave en la solución del problema aquí planteado, sobre el que volveré más adelante.

Pudiera parecer, de entrada, que el tema así planteado quedó resuelto por el artículo 71.2. LJCA que, si se interpreta en su sentido literal, no contempla esa posibilidad, al disponer que: «Los órganos jurisdiccionales no podrán determinar la forma en que han de quedar redactados los preceptos de una disposición general en sustitución de los que anularen ni podrán determinar el contenido discrecional de los actos anulados». Este precepto recoge un importantísimo contrapeso del poder legislativo al poder judicial frente al poder ejecutivo. En efecto, implica una auténtica contención del poder judicial para evitar abusos de jurisdicción e intromisiones ilegítimas en el ámbito reservado al poder discrecional de la Administración. No en vano, el Tribunal Supremo ha considerado en no pocas ocasiones, como se podrá comprobar en este trabajo, que este tipo de extralimitaciones constituye un abuso en el ejercicio de la jurisdicción, abriendo la vía, por consiguiente, a la casación, a través del anterior artículo 88.1.a) de la LJCA, según el cual el recurso de casación podía basarse, de entre otros motivos, en el abuso, exceso o defecto en el ejercicio de la casación. Y, de conformidad con la nueva regulación del recurso de casación, prevista en la Disposición Final tercera de la Ley Orgánica 7/2015, de 21 de julio, del Poder Judicial, una infracción en el ejercicio de la jurisdicción, que puede fundamentar un recurso de casación, como se contempla en el art. 88.1, al señalar que: «El recurso de casación podrá ser admitido a trámite cuando, invocada una concreta infracción del ordenamiento jurídico, tanto procesal como sustantiva, o de la jurisprudencia, la Sala de lo ContenciosoAdministrativo del Tribunal Supremo estime que el recurso presenta interés casacional objetivo para la formación de jurisprudencia». Así, el TS subraya que el exceso o el abuso jurisdiccional constituye un supuesto de casación en el que la infracción radica en la extralimitación de la decisión judicial, por la invasión del terreno de otros órdenes jurisdiccionales o por la ilegítima intromisión en la esfera de decisión o ámbito de competencia de otros poderes del Estado, interviniendo fuera de los supuestos legalmente establecidos y más allá del control de la actividad de las administraciones públicas que a los tribunales les tienen reservado los artículos $106.1,117.3$ y 153.c) de la Constitución española. Desde esta perspectiva, el TS no considera que deba derivarse hacia el exceso de jurisdicción cualquier aplicación o interpretación jurídica desacertada por el tribunal de instancia, que podrá constituir, en su caso, un error, pero no por ello constituye necesariamente un exceso de jurisdicción, pues de ser así todos esos desaciertos habrían de canalizarse por el cauce casacional de la letra a) del artículo 88.1 de la Ley de la Jurisdicción. El exceso denunciable por dicho cauce casacional tiene lugar, a modo de ver del Alto Tribunal, cuando los órganos del poder jurisdiccional invaden el ámbito 
de actuación que corresponde a otros poderes, ejercitando las atribuciones que son propias de estos últimos, pero no hay exceso cuando el juez ejercita su labor de control de legalidad que corresponde a la jurisdicción sobre el ejercicio de las potestades administrativas (STS de 6905/2011, de 31 de octubre, rec. 3977/2009; STS 8937/2011, de 12 de diciembre de 2011, rec. 4575/2008; STS 5937/2012, de 17 de septiembre, rec. 5075/2009; ATS 10318/2014, de 13 de noviembre, rec. 310/2014; STS 3279/2016, de 24 de junio, rec. $1444 / 2015$, entre otras resoluciones). En este trabajo, por consiguiente, estudiaré la vulneración del artículo 71.2 debido a una infracción de las normas en el ejercicio de la jurisdicción [arts. 81.a) de la LJCA en su redacción dada hasta 2015 y 88.1 en la LJCA tras la reforma del mismo año], analizando los diferentes supuestos que emanan de la jurisprudencia ${ }^{2}$.

En una interpretación literal del artículo 71.2 LJCA, el Tribunal debe limitarse a anular los preceptos de un reglamento que sean incompatibles con el ordenamiento y no podrá sustituir en ningún caso su texto, sino que esta tarea corresponderá a la Administración. Tampoco podrá predeterminar la opción, de entre las posibles, al anular un acto discrecional. Los jueces no deben, a través del control judicial, sustituir a los Gobiernos y Administraciones en la determinación de los aspectos puramente políticos o técnicos de sus decisiones, pues se excederían en su función de juzgar, alterando la división de poderes ${ }^{3}$. Por ello, el juez puede anular una decisión discrecional que suponga una extralimitación con respecto de lo que previene la ley pero no debe rellenar el vacío que se genera. Menos aún si son posibles varias decisiones según criterios técnicos o políticos. Esta sería la interpretación más o menos fiel de la letra de la ley.

2 Téngase en cuenta que el Tribunal Supremo también ha aceptado la vulneración del artículo 71.2 por vulneración de las normas del ordenamiento jurídico o de la jurisprudencia que fueran aplicables para resolver las cuestiones objeto de debate [88.1.d)], motivo en el que podía fundarse el viejo recurso de casación y que actualmente encaja en el fundamento genérico del art. 88.1. No es generalizada, sin embargo, la consideración de la vulneración de dicho precepto por quebrantamiento de las formas esenciales del juicio por infracción de las normas reguladoras de la sentencia o de las que rigen los actos y garantías procesales, siempre que, en este último caso, se haya producido indefensión para la parte ex art. 88.1 c) de la vieja regulación y 89.2 c) de la nueva, según reiterada jurisprudencia (véase, por ejemplo, el ATS 12085/2013, de 12 de diciembre, rec. 1794/2013, FJ 2º. Encontramos una excepción a esta regla general en la STS 6309/2010, de 26 de octubre, rec. 4155/2007, que se comentará más adelante.

3 M. Sánchez Morón (2011), Derecho Administrativo. Parte General, 7ª ed., Madrid: Tecnos, pág. 109. 
A pesar del sentido literal de este precepto, algunas sentencias, en el seno del Tribunal Supremo, han seguido una línea jurisprudencial nacida con la vigencia de la Ley de la Jurisdicción de 1956, aparentemente más próxima a la idea de la función que ostenta la jurisdicción ex constitutione de control de la actividad de la Administración a los fines que la justifican, en base al art. 106 $\mathrm{CE}^{4}$. Línea que se pretendería erradicar con la nueva ley pero, como se tratará de mostrar en este trabajo, no se ha conseguido5.

4 Hay que apuntar sin falta que la LJ 1956 contemplaba una excepción en materia fiscal. En efecto, el artículo 85 disponía que los fallos que dictasen las Salas de lo ContenciosoAdministrativo en materia de ordenanzas fiscales, si anulaban el acto objeto del recurso, debían expresar concretamente la forma en que habían de quedar redactados los preceptos impugnados. Este precepto procedía de la legislación de régimen local. Tenía como finalidad evitar cualquier demora en la vigencia de las ordenanzas fiscales, y de la consiguiente recaudación, de manera que la anulación conllevaba que el Tribunal expresara cómo habían de quedar redactados los preceptos correspondientes, sin necesidad de los trámites necesarios si la sentencia fuere solo anulatoria y la corporación local hubiera de aprobar una nueva redacción (SSTS de 30 de abril de 1996 y de 18 de octubre de 1994).

5 En la Ley encontraríamos una primera matización. En efecto, volviendo a la referencia tributaria, si bien el contenido del artículo 85 de la LJ 1956 no se ha reproducido en la LJ 1998, se tomó en cierta manera en la legislación de haciendas locales. El texto refundido de la Ley reguladora de las Haciendas Locales, aprobado por el Real Decreto Legislativo 2/2004, de 5 de marzo, menciona en su art. 19.2 (recurso contenciosoadministrativo) la posible existencia de sentencias no solo anulatorias sino también de modificación de las ordenanzas fiscales municipales, en los siguientes términos: «Si por resolución judicial firme resultaren anulados o modificados los acuerdos locales o el texto de las ordenanzas fiscales, la entidad local vendrá obligada a adecuar a los términos de la sentencia todas las actuaciones que lleve a cabo con posterioridad a la fecha en que aquella le sea notificada. Salvo que expresamente lo prohibiera la sentencia, se mantendrán los actos firmes o consentidos dictados al amparo de la ordenanza que posteriormente resulte anulada o modificada». Esta norma proviene de la reforma que se llevó a cabo por la Ley 50/1998, de 30 de diciembre, también posterior a la LJCA y a su entrada en vigor. Por ello, diríamos que en materia de haciendas locales, interpretando el artículo 71.2 y el 19.2 LHL, la decisión judicial no podrá determinar «la forma en que han de quedar redactados los preceptos de una disposición general en sustitución de los que anularen", pero ello no debe impedir la necesidad de declarar aquellas modificaciones que sean indispensables para la comprensión del texto anulado o respondan a la corrección de errores materiales. Véase, en esta línea, la STS 6141/2013, de 31 de octubre, rec. 3256/2012, en la que se da por buena la interpretación conjunta, en el sentido indicado, de ambos preceptos, reflejada en la STSJ de Cataluña 748/2012, de 2 de julio, rec. 437/2011, así como la STS 140/2016, de 28 de enero, rec. 2126/2014. 
Como se podrá comprobar, la mayor parte de las sentencias recientes referidas a la cuestión a tratar se han dado en materia de urbanismo. De ahí que el desarrollo argumental se centre en buena parte en este ámbito del ordenamiento.

\section{ITER PARLAMENTARIO DEL ARTÍCULO 71.2 LJCA}

En la redacción original del proyecto de ley de la jurisdicción contencioso-administrativa, este precepto se completaba con la siguiente coletilla (art. 69.2): «salvo que, como consecuencia de la anulación, sólo sea posible una única solución y exista base para ello en los autos». Solución que parece lógica habida cuenta de que en este caso se produciría, en efecto, una sustitución pero sería más bien formal, no material, garantizándose que el derecho a la tutela judicial, que debe ser efectiva, no quede limitado a indicar que la Administración debe dictar una resolución, por lo que los jueces deberán decidir sobre aquello que la Administración debe resolver. En la exposición de motivos del proyecto de ley se indicaba que, efectivamente, el recurso contencioso-administrativo tiene una naturaleza de control en derecho, de ahí que se precise que los jueces y tribunales no pueden determinar el contenido discrecional de los actos que anulen. Sin embargo, esta regla, recalcaba el proyecto, no debe coartar en absoluto la potestad de los órganos judiciales de extender su control de los actos discrecionales hasta donde lo exija el sometimiento de la Administración al derecho. Es decir, mediante el enjuiciamiento de los elementos reglados de dichos actos y la garantía de los límites jurídicos de la discrecionalidad. Por ello, se añade una importante precisión, relativa a aquellos casos en los que, como consecuencia de la anulación del acto impugnado, solo sea posible una única solución razonable. En este supuesto, y siempre que exista base para ello en autos, el juez o tribunal puede determinar el contenido del acto discrecional anulado, consagrando así en la ley una progresiva jurisprudencia, especialmente preocupada por garantizar en estos casos la tutela judicial efectiva, concluía ${ }^{6}$.

6 Antes de la entrada en vigor de la LJCA 98 se había forjado una posición jurisprudencial y doctrinal inequívoca. Así, por ejemplo, la STS de 22 de octubre de 1990. En la doctrina, Javier Delgado Barrio (1993) decía, en materia urbanística, que los tribunales habrán de señalar la nueva calificación si las líneas del planeamiento conducen a una solución que se impone ya por razones de coherencia, citando las sentencias de 22 de septiembre y 15 de diciembre de 1986. Y remachaba esta idea indicando que ello viene exigido por el principio de efectividad de la tutela judicial ex artículo 24.1 de la Constitución, en su libro, El control de la discrecionalidad del planeamiento urbanistico, Madrid: Civitas, pág. 
Sin embargo, esta coletilla fue suprimida como consecuencia de la aceptación de una enmienda presentada por el Grupo Federal de Izquierda Unida. Se argumentó en la enmienda que la discrecionalidad permite la opción entre varias soluciones igualmente válidas en el marco de la ley, con lo que si como consecuencia de la anulación del acto solo queda una alternativa, entonces propiamente no se trataría de un acto discrecional y el precepto quedaría inaplicable, en los siguientes términos: «La discrecionalidad supone poder elegir entre varias alternativas igualmente justas, o entre indiferentes jurídicos, por fundarse la decisión en criterios extrajurídicos no incluidos en la ley y remitidos al juicio subjetivo de la Administración. Por consiguiente, si no hay posibilidad de elegir entre varias soluciones jurídicamente indiferentes, no cabe hablar de discrecionalidad y el precepto es conceptualmente inaplicable». A continuación, precisará que el contenido discrecional del acto no puede ser anulado autónomamente, sino como consecuencia del enjuiciamiento de sus elementos reglados; es decir, si en los aspectos reglados el acto se ajusta a derecho, no puede ser anulado por razón de su componente exclusivamente discrecional ${ }^{7}$. Y concluirá indicando que, en cualquier caso, la apreciación de

122. Igualmente, Francisco López Menudo (1996) decía que cuando la decisión judicial sustitutiva no viene conectada a alternativas distintas de las comprendidas en los autos mismos, en los que se agotan las opciones que la propia Administración ha puesto en juego, y aun dentro de ellas, cuando la alternativa escogida no tiene a todas luces alternativa posible, el mecanismo guarda más afinidad con el de control de la potestad reglada que con una supuesta sustitución pura de las decisiones administrativas discrecionales, en su trabajo, "El control judicial de la Administración en la Constitución Española», Discrecionalidad administrativa y control judicial. I Jornadas de estudio del gabinete juridico de la Junta de Andalucía, Madrid: Civitas, pág. 41. Con el artículo 71.2 LJCA se plantearán más dudas, como se desarrollará más adelante. También son de cita necesaria las monografías de la época de M. Bacigalupo Sagesse (1997), La discrecionalidad administrativa: estructura normativa, control judicial y limites constitucionales de su atribución, Madrid: Marcial Pons; M. Beltrán de Felipe (1995), Discrecionalidad administrativa y Constitución, Madrid: Tecnos; E. Desdentado Daroca (1997), Discrecionalidad administrativa y planeamiento urbanistico: construcción teórica y análisis jurisprudencial, Pamplona: Aranzadi; y el artículo de T.-R. Fernández Rodríguez (1992), «Juzgar a la Administración contribuye también a administrar mejor», REDA, 76, págs. 511-532.

7 BOCG. Congreso de los Diputados, núm. A-70-9 de 10/03/1998. Al respecto discrepa en nuestra doctrina el profesor Tomás-Ramón Fernández. Argumenta que «[...] es obvio que la verificación de los elementos reglados del acto administrativo no implica, por hipótesis, control alguno de la discrecionalidad decisoria reconocida a la Administración por la Ley, sino solo la comprobación de algo que es previo a la decisión misma y, por lo tanto, conceptualmente ajeno a la libertad de elección entre varias soluciones posibles en que el poder discrecional consiste». Véase Fernández Rodríguez (1992: 524). 
si existen otras soluciones justas corresponde a la Administración — sin perjuicio de su ulterior control-, la cual no puede verse suplantada por el órgano jurisdiccional en una función que le es ajena, cual es la de administrar ${ }^{8}$. Esta línea, en efecto, supone una aplicación rigurosa del concepto de separación de poderes, priorizándolo frente a otros intereses en conflicto, primordialmente el derecho a la tutela judicial efectiva, pues con ello se favorece una solución demorada del conflicto, lo que puede quebrar, por lo tanto, el anhelo de una buena administración de la justicia, que debe tener en la celeridad uno de sus fundamentos irrenunciables.

Aunque, como he dicho, la coletilla desapareció tras el informe de la ponencia, ha habido sentencias posteriores en las que se ha determinado el contenido discrecional de un acto o disposición cuando solo queda una alternativa posible. E incluso se habrá ido más allá. Por ello, so pretexto del derecho a la tutela judicial efectiva, también habrá decisiones judiciales que sustituyan el criterio de decisiones administrativas, en supuestos en los que se dan diferentes soluciones justas posibles, mudando el ejercicio de la función de control judicial legalmente encomendada en otra de determinación de la decisión administrativa, en un claro exceso en el ejercicio de la función jurisdiccional.

No hay que negar que, en muchas situaciones, puede resultar contrario a derecho, en términos de justicia material, que tras un largo procedimiento contencioso-administrativo, la sentencia se limite a decir que la Administración debe anular lo hecho erróneamente o que se retrotraigan las actuaciones. Sin embargo, lo contrario, esto es, la sustitución judicial de la decisión administrativa, interfiere en el ámbito propio de la Administración, estando proscrito por la ley, como se ha visto. El juez no puede sustituir a la Administración en la toma de las decisiones que le son propias, ya que estaría predeterminando asuntos que se refieren al funcionamiento de la Administración pública y a los servicios que esta presta a los ciudadanos. Estaría ocupando así, de un modo irregular, el espacio encargado a los representantes elegidos democráticamente por los ciudadanos, asumiendo la potestad en la toma de decisiones que implica gobernar a los ciudadanos.

El juez, en efecto, podrá controlar el ejercicio de las potestades discrecionales por parte de la Administración, pero una vez realizado el examen del sometimiento de la actuación de la Administración a la ley, se encontrará con el límite de que la facultad de definir la actuación, de decidir la concreta aplicación de conceptos jurídicos determinados, compete al poder ejecutivo, no al judicial. El juez podrá decir que la Administración se ha excedido en el

8 BOCG. Congreso de los Diputados, núm. A-70-8 de 24/11/1997. Enmienda núm. 123 , pág. 82 . 
ejercicio de la discrecionalidad y anular su actuación, pero no podrá predeterminar otra actuación, sino que el hueco deberá rellenarlo después la propia Administración. Contemplado así el problema, nos podemos preguntar si la exigencia constitucional de que el juez controle la legalidad de la actuación de la Administración, así como el sometimiento de esta a los fines que la justifican, queda completada en su totalidad. Se puede plantear, en efecto, si el juez estará vinculado por dicho mandato constitucional no solo al control de la legalidad de la actuación de la Administración, sino también a la vigilancia de su sometimiento al interés general, por lo que, quizá, ex constitutione no desencajaría la adopción de un papel judicial más activo.

\section{JURISPRUDENCIA DEL TRIBUNAL SUPREMO}

Se están planteando no pocos recursos de casación en los que se considera violado el artículo 71.2 LJCA por infracción de las normas referidas a la jurisdicción [art. 88.1 LJCA, en la actual regulación y art. 88.1.a), en la anterior regulación, como he adelantado anteriormente]. Como he avanzado antes, mayoritariamente tratan sobre la anulación de disposiciones urbanísticas contenidas en instrumentos de planeamiento y su sustitución por otras establecidas por el órgano jurisdiccional de instancia, infringiendo el art. 71.2 LJCA, en cuestiones referidas a delimitación del suelo ${ }^{9}$, aunque también se dan otros supuestos, como los referidos al sector eléctrico o la autonomía local en relación con las competencias autonómicas sobre urbanismo y ordenación del territorio. A continuación, glosaré una serie de supuestos de interpretación del artículo 71.2 LJCA y su conexión con la infracción de las normas referidas a la jurisdicción como fundamento de la casación, que he derivado del estudio y análisis de la jurisprudencia.

\section{EL TRIBUNAL NO INCURRE EN INFRACCIÓN EN EL EJERCICIO DE LA JURISDICCIÓN SI CONOCE DE UN ASUNTO SOBRE EL QUE TIENE JURISDICCIÓN}

Comenzaré el comentario de supuestos planteados en la jurisprudencia ofreciendo el más sencillo y, quizá, obvio. No nos encontraremos ante una infracción en el ejercicio de la jurisdicción cuando el tribunal ha conocido de un asunto sobre el que tiene jurisdicción, haya sido acertado o desacertado en

9 Sobre este tema, véase Ma C. de Guerrero Manso (2011), La ciudad existente: delimitación del suelo urbano y en situación de urbanizado, Madrid: Iustel. 
su resolución. No procederá, así, acoger los motivos casacionales deducidos al amparo del artículo 88.1 LJCA, cuando las pretensiones de anulación y de plena jurisdicción ejercitadas por los demandantes se deducen como establece el artículo 1 de la misma en relación con la actuación de las administraciones públicas sujetas al derecho administrativo (arts. 31 y 32 LJCA). La Sala a quo, con independencia del acierto o desacierto en la resolución habrá conocido de un asunto para el que tiene jurisdicción. Así se plantea sin mayor problema en la STS 5503/2015, de 17 de diciembre, rec. 273/2014, FJ 4º. Eso sí, este supuesto es aplicable a los casos en los que el tribunal conoce de un asunto sobre el que tiene jurisdicción y su labor se limita a la anulación y, en su caso, ejecución, sin añadir más al contenido de su fallo.

\section{EL TRIBUNAL NO PUEDE SUSTITUIR LA DECISIÓN DE LA ADMINISTRACIÓN CUANDO SON POSIBLES VARIAS ALTERNATIVAS}

El análisis de este supuesto lo realizaré tomando como referencia principal la STS 2611/2011, de 29 de abril, rec. 1755/2007 (ponente: Jorge Rodríguez-Zapata). Este asunto tenía su origen en la revisión del plan general de ordenación urbana de Sant Pere de Ribes, que implicaba en una unidad de actuación cesiones de suelo público: a) para parques, jardines y plazas públicas; b) red viaria urbana; y c) reserva de equipamiento.

Como resultado se obtiene como calificación de suelo privado: ciudad jardín en unifamiliar y plurifamiliar (intensidad II); y equipamiento sanitario asistencial de titularidad privada, en el que solo se admite planta baja más una planta principal.

La entidad mercantil Alimasma S.L. impugnó la nueva ordenación contemplada en la modificación del plan, al considerarla inviable técnica y económicamente. En relación con la posibilidad de establecer un equipamiento sanitario asistencial, considera que la edificabilidad prevista es antieconómica, con lo que propone un aumento significativo (antecedente de hecho $2^{\circ}$ ).

El TSJ estimó parcialmente el recurso. Se acogió a un informe pericial y estableció nuevos parámetros de edificabilidad, de entre las diferentes posibilidades que contempla la ley. El TS en casación indicará que una jurisdicción formalmente correcta puede incurrir en un ejercicio abusivo al sustituir a la Administración autora del planeamiento urbanístico, en su poder de decisión, respecto a determinaciones que constitucionalmente le corresponden, en los siguientes términos:

QUINTO.-[...] la infracción que se alega en el motivo constituye dogmáticamente un abuso de jurisdicción, aunque se haya cometido en la fase de decisión del proceso, ya que la Sentencia sustituye a la Administración 
al decidir adoptando determinaciones que no tienen una alternativa única y que, por tanto, siguen correspondiendo constitucionalmente en exclusiva a la Administración autora del planeamiento urbanístico. [...] [En términos similares, aunque en sentido desestimatorio, Sentencias de 27 de abril de 2004, rec. 308/2002, de 2 de junio de 2008, rec. 3416/2004, de 25 de marzo de 2010, rec. 5635/2006, 2174/2016, de 17 de mayo, rec. 1732/2015].

A continuación, subrayará una idea clave que ya sería adelantada por la doctrina años antes. Me refiero a la prohibición del abuso de jurisdicción en base al derecho a la tutela judicial efectiva, del que también son titulares las administraciones públicas:

SEXTO.-Es de añadir que el abuso o exceso de jurisdicción, además de ser un vicio que debe ser corregido en casación por el artículo 88.1 a) LRJCA, está prohibido por el derecho fundamental a la tutela judicial efectiva (SSTC 58/2004, de 19 de abril, FJ 3 y 212/2003, de 1 de diciembre, FJ 3 y ATC 148/1999, de 14 de junio, FJ 1 con remisión a otra jurisprudencia). La Generalitat de Cataluña es titular de ese derecho en el presente caso (SSTC 175/2001, de 26 de julio, FFJJ 5,6 y 7 y 78/2010, de 20 de octubre, FJ 6) ${ }^{10}$ [...].

SÉPTIMO.-[...] en el control de la denominada discrecionalidad técnica del planificador urbanístico el Derecho no siempre proporciona al Tribunal todos los datos necesarios para sustituir el acto administrativo por el jurisdiccional, por lo que, en dicha medida, la actividad discrecional no resulta enteramente enjuiciable jurisdiccionalmente.

Cuando en la actividad discrecional resultan posibles varias soluciones todas igualmente lícitas y justas - y por tanto indiferentes para el Derecho- entre las cuales hay que elegir con criterios extrajurídicos, existe un núcleo último de oportunidad en el que no cabe sustituir la decisión administrativa por una decisión judicial. [...]

Todo ello sin perjuicio de las evidentes excepciones, que no se dan en este caso, en las que como resultado del proceso la coherencia de la decisión administrativa pueda imponer una única solución; solución ésta que implicaría, al ser única, la desaparición de la discrecionalidad ${ }^{11}$.

10 En la doctrina, véase en este sentido, M. Sánchez Morón (1994), Discrecionalidad administrativa y control judicial, Madrid: Tecnos, pág. 160.

11 Idea esta última que encaja con el espíritu de la enmienda que se realizó al art. 69.2, de la que resultaría el actual art. 71.2 LJ 1998, como se ha seńalado anteriormente. Al respecto, será de interés la valiosa doctrina del agotamiento de la discrecionalidad en el derecho alemán, que ofrece A. Huergo Lora (2000), Las pretensiones de condena en el contencioso-administrativo, Pamplona: Aranzadi, págs. 323 y ss. 
Aplicará estos principios generales al caso concreto, concluyendo que el TSJ ha sustituido una decisión discrecional del planificador urbanístico, determinando una opción de entre varias legalmente posibles, en los siguientes términos:

OCTAVO.-[...] la Sala de instancia [...] atribuye directa e imperativamente a la misma un techo edificatorio que ciertamente era necesario para desarrollar la actividad prevista pero no la única solución urbanística alternativa frente a la solución descartada como contraria a Derecho.

[...] Es preciso subrayar que la misma prueba pericial que obra en autos admite la rentabilidad de una residencia de ancianos de 90 plazas, con posibilidad de Centro de día, con sólo 2495, $90 \mathrm{~m}^{2}$ de edificabilidad sobre rasante y 1011, $95 \mathrm{~m}^{2}$ bajo rasante si el terreno lo permite y la Sentencia decide conceder la totalidad de la edificabilidad sobre rasante, pese a las contingencias que plantea el propio informe pericial. [...].

A contrario, este argumento podría significar, siguiendo la lógica argumentativa de esta sentencia, que cuando los informes periciales contemplen una solución como válida, podrá darse por buena y, por consiguiente, sustentar la base de la sustitución de otro posible criterio de la Administración ${ }^{12}$. En

12 En esta línea, puede citarse la Sentencia de la Audiencia Nacional 48/2009, de 14 de enero, rec. 144/2007. Se trata de la resolución de un recurso interpuesto por un catedrático de Universidad contra la denegación por parte del Ministerio de Asuntos Exteriores y de Cooperación de la financiación económica solicitada, dentro de la convocatoria publicada y en régimen de concurrencia competitiva, a un proyecto de cooperación universitaria e investigación científica. El problema se suscitó por los criterios de valoración de los diferentes méritos, ya que la Comisión de Evaluación estableció una doble nota de corte, de 3 y 3,5 de evaluadores internos y externos, que no constaban en las bases de la convocatoria. El demandante habría obtenido una puntuación media de 3,5 sobre 5 , si bien obtuvo una calificación inferior de las requeridas en una de las notas de corte. La Audiencia Nacional determinará que el recurrente tiene derecho a la concesión de la ayuda siempre que entre los proyectos que han sido admitidos obre alguno cuya puntuación media de los cuatro criterios sea igual o inferior a 3,5 puntos, que es la obtenida por el presentado por el recurrente, puesto que la valoración positiva del proyecto la encuentra acreditada la Sala como resultado de la pericial practicada, en cuyo caso, la cuantía de la ayuda será la solicitada, de 15000 euros, «pues su adecuación viene avalada por las dos periciales judiciales practicadas, con intervención de las partes, cuya argumentación lógica no ha sido desvirtuada de contrario y que llevan a la Sala a formar su convicción sobre el particular» $\left(\mathrm{FJ} 4^{\circ}\right)$. Es decir, la Audiencia Nacional está sustituyendo a la Administración en la adopción de una decisión típicamente discrecional al resultarle razonable la valoración realizada por los peritos, impidiendo la posibilidad de que la 
cualquier caso, el TS concluye censurando la sustitución judicial de la decisión discrecional de la Administración, en los siguientes términos:

La Sala a quo no se ha limitado a controlar la legalidad de la actuación urbanística y su sometimiento a las normas que la justifican (artículos 106.1 CE y 8 LOPJ) sino que ha sustituido en su sentencia la voluntad de la Administración urbanística, determinando en forma imperativa la forma en que tiene que quedar redactada la Unidad de actuación litigiosa, cuando ésta admite otras soluciones posibles en sustitución de la prevista en el Plan ${ }^{13}$.

Esta doctrina jurisprudencial ha sido asumida en sentencias posteriores referidas también a cuestiones urbanísticas. Así, en la STS 6158/2012, de 27 de septiembre, rec. 5234/2010 (ponente: Eduardo Calvo Rojas), sobre la incorporación por el Plan General de Ordenación Urbana del Ayuntamiento de Els Alamús (Lérida) de unos terrenos en el suelo urbanizable, así como en las Sentencias 2611/2011, de 29 de abril, rec. 1755/2007, y 5573/2013, de 15 de noviembre, rec. 6323/2010.

\section{3. ¿̇PUEDE EL TRIBUNAL SUSTITUIR LA DECISIÓN DE LA ADMINISTRACIÓN CUANDO SOLO ES POSIBLE UNA ALTERNATIVA?}

La lectura y análisis de ambas sentencias — la 2611/2011, de 29 de abril y la 6158/2012 - parece que permite considerar que se aceptará la determinación judicial en los casos en los que exista una alternativa única. Debemos diferenciar a este respecto si ha habido abuso o exceso de jurisdicción de si ha habido una infracción del artículo 71.2 LJCA. A este debate se refiere la STS de 15 de julio de 2011, rec. 5332/2007 (ponente: Mariano de Oro Pulido), sobre la aprobación definitiva del Plan General de Ordenación Urbana de Arenys de Munt, en el que se calificaba una finca como «construcción singular», en los siguientes términos:

[...] La cuestión realmente controvertida en este caso no es, pues, discernir si ha habido o no un exceso de jurisdicción, que realmente aquí no lo hubo,

Administración — por razones técnicas, y en valoración del proyecto de investigación-, que es el poder al que se ha encomendado la tarea, pueda fijar una cantidad diferente.

13 Véase un comentario a esta sentencia en el trabajo de T. Font i Llovet y O. Mir Puigpelat (2012), "Discrecionalidad administrativa y alcance del control judicial», en Administración y Justicia: un análisis jurisprudencial: liber amicorum Tomás Ramón Fernández, vol. 1 (coords. Eduardo García de Enterría Martínez-Carande y Ricardo Alonso García), Cizur Menor: Civitas, págs. 1147-1156. 
sino más bien determinar si acertó la Sala de instancia al considerar que esa doctrina jurisprudencial a que hizo referencia en su sentencia efectivamente le habilitaba para fijar una determinación de tal índole en la propia sentencia, esto es, para fijar ya en su sentencia la calificación procedente para la finca concernida, por encima de lo dispuesto en el tan citado artículo 71.2 de la Ley Jurisdiccional.

Y es que, en puridad, de la letra de la ley se desprende que el juez no tendría esa potestad, si bien en estos casos se ha optado por la protección de la tutela judicial efectiva, como se ha dicho antes. El tribunal considera que no ha habido un exceso de jurisdicción en el bien entendido de que en base al derecho a la tutela judicial el tribunal debe determinar la única solución posible, con lo que no habría infracción de las normas referidas a la jurisdicción. Sin embargo, no queda tan claro, como decía, que el artículo 71.2, en una interpretación literal y formal, no quede vulnerado, pues es nítido al indicar que el tribunal no podrá «[...] determinar la forma en que han de quedar redactados los preceptos de una disposición general en sustitución de los que anularen [...]». En apoyo de esta tesis, hay que recordar la coletilla que inicialmente recogía este precepto «salvo que, como consecuencia de la anulación, sólo sea posible una única solución y exista base para ello en los autos», que fue suprimida en el iter parlamentario de la ley, como he glosado anteriormente.

\section{EL TRIBUNAL PODRÁ CORREGIR LA DECISIÓN DE LA ADMINISTRACIÓN CUANDO NO SE HAYA REALIZADO CORRECTAMENTE LA SUBSUNCIÓN DE LOS HECHOS EN EL SUPUESTO DE LA NORMA}

Estas dudas no se plantean, por el contrario, en una sentencia anterior. $\mathrm{Me}$ refiero a la STS 6309/2010, de 26 de octubre, rec. 4155/2007 (ponente: Rafael Fernández Valverde), sobre el Plan de Ordenación de los Recursos Naturales («PORN», en adelante) de las Marismas de Santońa, Victoria y Joyel. En este caso, el TS viene a decir que el tribunal podrá sustituir la decisión de la Administración cuando no haya realizado una correcta subsunción de los hechos en el supuesto de la norma ${ }^{14}$. En concreto, el TS recuerda que la potestad de planea-

14 Línea sobre la que se insiste también en otros ámbitos sectoriales. Así, la STS 1274/2016, de 16 de marzo, rec. 396/2013, concluye que el juez no se ha excedido en su jurisdicción al ordenar incluir, en base a la información técnica y científica disponible, determinadas especies en el Catálogo Espańol de Especies Exóticas Invasoras. Se considera que no hay ámbito de discrecionalidad administrativa, pues, desde un punto de vista técnico, una especie es invasora o no lo es (FJ $3^{\circ}$ ). En cambio, observa 
miento incluye una parte reglada y una parte discrecional. En base a ello, la Administración, al calificar las diferentes zonas incluidas en el PORN, debe atender al marco normativo y a la realidad fáctica, de tal manera que el Tribunal puede corregir la calificación realizada por la Administración si no hay una correspondencia entre la Ley y la parte reglada del PORN, por un lado, y la realidad fáctica, por otro, con respecto de la calificación realizada por la Administración de cada zona incluida en el ámbito del instrumento de ordenación (FJ 10):

[...] la zona de Hornos (en Argońos) ha quedado calificada como Zona de Uso Intensivo, en vez de Zona de Uso Especial que disponía el PORN. Tal decisión es consecuencia de la función revisora que, desde una perspectiva de legalidad, corresponde a este orden jurisdiccional; [...] la Sala de instancia no se extralimita ni sustituye a la Administración, sino que, simplemente, determina y concreta cuál es la auténtica categoría fáctica de dicha zona y, en consecuencia, procede a aplicarle el régimen jurídico correspondiente a tal situación, de entre los ya previstos y regulados en el PORN.

Parece que había más de una alternativa, con lo que el juez habría controlado la actuación de la Administración, concretando la opción que, en base a la ley y la realidad fáctica, observa acertada:

[...] el juzgador de instancia, tras el examen de las alegaciones de las partes y el preceptivo proceso de valoración probatoria, elige, concreta y especifica —insistimos, desde una perspectiva de legalidad - el régimen de protección correspondiente a la zona objeto de ordenación, y, al no resultar correcto el determinado en el PORN, lo sustituye por el que cuenta con tal consideración de corrección jurídica. En síntesis, [...] no es la Sala la que configura jurídicamente dicha zona [...] pues, las características de dicho régimen (Zona de Uso Intensivo) ya estaban, como decíamos, previstas y configuradas en el mismo Plan por parte de la Administración que lo aprobó.

[...] Desde una perspectiva constitucional la actuación de la Sala de instancia se ha movido en el ámbito de actuación que para esta jurisdicción se contempla en el artículo 106 de la Constitución Española, que no solo se extiende al control del ejercicio de la potestad reglamentaria por parte de las Administraciones públicas, sino que también se extiende a la comprobación de los fines que justifican tal actuación.

Esta última apreciación no carece de significado. En efecto, en la tramitación del artículo 104 del Anteproyecto de Constitución (actual artículo 106 CE), el Grupo Parlamentario Socialista del Congreso propondría una

que no debe dictaminar cómo debe quedar redactado finalmente el precepto, entroncando con el art. 71.2 (FJ 9o). 
enmienda, según la cual, se pretendía que este precepto quedara redactado de la siguiente manera:

1. Toda la actividad de la Administración pública está sometida al control jurisdiccional plenario y efectivo.

2. Los Tribunales controlarán la sumisión de la Administración a la Ley y al Derecho y el servicio a los fines que justifican su actuación, declaran las responsabilidades patrimoniales por las lesiones injustas que su actividad ocasione a los ciudadanos y suplen la omisión de actividad de la Administración cuando tal actividad es legalmente obligada (BOC, 44, de 5 de enero de 1978).

El senador Lorenzo Martín-Retortillo defendió una redacción más sintética, que se aproximaba a la que finalmente se mantuvo:

Los Tribunales controlan, sin excepciones, la potestad reglamentaria, así como las actuaciones y omisiones administrativas, juzgando de su legalidad y adecuación a sus fines.

En ambas enmiendas, Eduardo García de Enterría tuvo mucho que ver, como refleja Martín-Retortillo en su libro Materiales para una Constitución. Los trabajos de un profesor en la comisión constitucional del Senado ${ }^{15}$. Fórmula abierta, la planteada por el senador, que dará cobertura a diferentes interrogantes, con la finalidad de no establecer criterios cerrados ni predeterminados, que pueden resultar decisivos. El profesor Martín-Retortillo subrayaría poco después la importante labor a la que están llamados los jueces de lo contencioso en base al artículo $24 \mathrm{CE}$ en la ejecución de las sentencias, revisando decisiones de la Administración, campo vedado antes de la Constitución. No obstante, también dirá que una cosa es afirmar la competencia del tribunal, la posibilidad de control, y otra afirmar que el tribunal tenga elementos de juicio para sustituir al órgano administrativo en una determinada decisión. Y continúa razonando que reconocer el control no implica proclamar sin más que de forma automática los tribunales vayan a ocupar la plaza de los órganos administrativos, aun en los asuntos más delicados y espinosos, en los que el tomar decisiones suele exigir un grado de preparación especializada del que carecen los tribunales. El control, allí donde haya elementos controlables, no equivale a la libertad de los jueces para que decidan en ámbitos en los que la ley no ha querido encomendarles ${ }^{16}$.

15 L. Martín-Retortillo (1984: 280-281).

16 L. Martín-Retortillo (1981), «Evolución reciente del contencioso-administrativo», RAP, 95. 
En base a la enmienda del Grupo Socialista se podía entender que el tribunal puede suplir a la Administración en su actividad reglada e incluso en los elementos reglados de los actos discrecionales. Sin embargo, una vez que la ponencia designada al efecto concluyó el estudio de las enmiendas presentadas al anteproyecto de Constitución, el informe de la ponencia refundiría ambos apartados, según se indica textualmente $(B O C$, 82, de 17 de abril de 1978), dejando el precepto en la redacción que se ha mantenido en el texto definitivo: «Los tribunales controlan la potestad reglamentaria y la legalidad de la actuación administrativa, así como el sometimiento de ésta a los fines que la justifican». Por consiguiente, como la ponencia refunde ambos apartados en este único final, puede realizarse una interpretación del precepto actual teniendo en cuenta sus avatares parlamentarios, entendiendo incluida la coletilla introducida en la enmienda. Adquiere así especial relevancia la cita que hace la sentencia que ahora comento - la STS 6309/2010 - del artículo 106 $\mathrm{CE}$, recalcando que este precepto no solo se extiende al control del ejercicio de la potestad reglamentaria por parte de las administraciones públicas, sino que también a la comprobación de los fines que justifican tal actuación, ámbito en el que encaja la fiscalización judicial respecto del sometimiento al fin legítimo que la ley encomienda al ejercicio de la discrecionalidad.

Dicho de otro modo, el juez contencioso-administrativo tendrá como misión el control de la Administración con la finalidad de que se lleve a cabo «una buena Administración», esto es, una Administración que atiende a los fines que la justifican. Si el fin de la Administración es el servicio al interés general, el juez de lo contencioso deberá vigilar, controlar y participar, si procede, en la consecución del mismo ${ }^{17}$.

17 Ello cumplido siempre deberá tenerse bien presente que el límite del control judicial vendrá dado precisamente en el ejercicio de la legítima discrecionalidad que le corresponde a la Administración, entrando en juego el poder judicial en caso de extralimitación. Es muy clarificadora la línea mantenida al respecto por el TS en diversas sentencias, como, por ejemplo, la 1144/2016, de 16 de marzo, rec. 3415/2016 (FJ 8o); o la 2331/2016, de 18 de mayo, rec. 1763/2015 (FJ 6º), ponente: Francisco José Navarro Sanchís, que delimitan nítidamente el ámbito del 106 CE en relación con el 71.2 LJCA, en los siguientes términos: «La razón de ser de la limitación que impone a la labor jurisdiccional el citado artículo 71.2 de la LJCA — de ahí que el cauce empleado en casación para dar curso a tal reproche acostumbra ser el de la letra a) del artículo 88.1 , como aquí acontece, en tanto su transgresión puede suponer un verdadero exceso de jurisdicción - reside en el hecho de que, por mandato constitucional —art. 106.1 CE_ “ "1. Los Tribunales controlan la potestad reglamentaria y la legalidad de la actuación administrativa, así como el sometimiento de ésta a los fines que la justifican [...]", función institucional que debe ser plena e íntegra a la hora de llevar a término 
Volviendo a la Sentencia 6309/2010, el TS concretará la interpretación abstracta referida al control jurisdiccional del sometimiento de la Administración a los fines que la justifican, al caso concreto, en los siguientes términos:

Partiendo del ya descrito ámbito de actuación de los PORNs, como instrumentos que cuentan con la esencial finalidad de protección medioambiental, obvio es, que la Sala de instancia actuó dentro de los expresados límites de esta jurisdicción cuando, desde la perspectiva de dicha finalidad, procedió a comprobar la corrección de la zonificación y protección llevada a cabo por el PORN para los lugares afectados por el recurso, señalando y atribuyendo, en caso de inadecuación, el régimen jurídicamente correcto y adecuado a las características de la zona, de entre los ya previstos en el mismo PORN.

[...] se ha tratado de un debate que pudiéramos calificar de bilateral o multilateral tendente —como así ha ocurrido- a la exacta concreción del régimen jurídico de protección — de entre los previstos en el PORN—correspondiente a dicha zona; y en dicho debate no ha existido indefensión para las partes por cuanto las periciales y demás pruebas tomadas en consideración [...] han ido dirigidas a la determinación de la auténtica naturaleza de la zona en su integridad para, con posterioridad, proceder a la adjudicación del régimen de protección jurídicamente correcto y adecuado.

La línea presentada por esta sentencia se habría adelantado en una anterior, cuyo ponente es también el magistrado Rafael Fernández Valverde. Me refiero a la STS 1363/2010, de 2 de marzo, rec. 239/2006. El Tribunal comenzará su argumentación indicando que, en principio, los tribunales no

la fiscalización de los actos y disposiciones de la Administración, confrontándola con el ordenamiento jurídico, incluido el control sobre su sometimiento a los fines propios y específicos que la ley le encomienda. Tal potestad judicial exclusiva (art. 117 $\mathrm{CE}$ ), no obstante, debe detenerse ante el núcleo mismo de la discrecionalidad, como este Tribunal Supremo ha declarado constante y reiteradamente, de suerte que no es admisible, con ocasión del control judicial de los actos de la Administración, sustituir finalmente a esta en la toma de decisiones que le corresponden legítimamente, en el ejercicio de las potestades discrecionales que la ley le otorga. En otras palabras, el artículo 71.2 de la LJCA establece dos límites extrínsecos a la función de enjuiciamiento, pues rebasarían la potestad judicial para adentrarse ilícitamente en el campo de las potestades administrativas: así, los órganos jurisdiccionales no podrán: 1) determinar la forma en que han de quedar redactados los preceptos de una disposición general en sustitución de los que anularen; 2) tampoco podrán determinar el contenido discrecional de los actos anulados. Ambas son manifestaciones de una misma prohibición de sustraer a la Administración sus potestades propias, siendo la primera una norma especial sobre la más genéricamente enunciada en segundo lugar». 
pueden sustituir las decisiones discrecionales de la Administración, lo cual, strictu sensu, no encajaría con la redacción del art. 71.2 LJCA (FJ 5º). A continuación, matizará que el control judicial de la discrecionalidad no debe quedarse en lo formal, sino que debe entrar en el examen de lo sustantivo, del ejercicio correcto de la discrecionalidad, teniendo en consideración la realidad fáctica:

[...] el control judicial [...] ha de penetrar en la forma de dicho ejercicio mediante la revisión de los hechos y del uso proporcionado y racional de la potestad. Es deber moral y jurídico de los Tribunales no estar a las soluciones simples y sencillas, sino intentar indagar y establecer si la delegación de facultades en que consiste en último término la discrecionalidad ha sido utilizada de forma correcta y racional, sin incurrir en abuso o desviación de poder. En otras palabras, ante la discrecionalidad, la Jurisdicción contenciosa debe proceder a un control no sólo formal de legalidad, sino sustantivo del uso de la potestad en términos de comprobación de la adecuación entre los hechos determinantes y la decisión tomada ${ }^{18}$.

18 También resultará de interés, en fin, la cita de la STS 3414/2013, de 6 de julio, rec. 4284/2010 (ponente: José Juan Suay Rincón), en la que el TS da por buena la toma de postura del tribunal de instancia, al anular la clasificación del suelo como suelo no urbanizable realizada por la Administración superior (comunidad autónoma) e indicar, a la luz del informe técnico disponible, que debe darse al suelo la clasificación y calificación por la que optó el municipio (FJ 2० B): «[...] no cabe apreciar desde la perspectiva que ahora nos ocupa la concurrencia de la incongruencia aducida, porque, frente a las consideraciones sobre la naturaleza del suelo, el modelo urbanístico adoptado y las exigencias de la población efectuadas por el informe de la Generalitat de 27 de abril de 2005 y que están asimismo en la base de la reconsideración o rectificación de la aprobación provisional efectuada por la Corporación municipal, la Sala se inclina por las consideraciones realizadas a estos mismos efectos, justamente, por la aprobación provisional, de 15 de diciembre de 2004, que otorgó al suelo del Sector SUD 47 Camí de la Guingueta d'Ix la clasificación y calificación de "suelo urbanizable delimitado"». Este acuerdo de aprobación provisional, y con él el modelo al que responde, es el que la Sala de instancia hace valer, sobre la base de las consideraciones que asimismo expresa: «Desde luego el detenido estudio de las actuaciones municipales seguidas a partir de la recepción de la imposición por la Administración Autonómica de la exclusión de la clasificación como Suelo Urbanizable Delimitado - por su acuerdo de 27 de abril de 2005- hasta inclusive el revelador informe municipal de 24 de marzo de 2006 en sede de recurso de alzada revelan con claridad y suficiencia que la imposición de clasificación a la Administración Municipal y el tiempo que se iba acumulando en la tramitación de la figura del planeamiento obligaba a la Administración Municipal a no demorar temáticas urgentes tales como la de la escuela primaria y para el nuevo 
Se trata, por consiguiente, de una decidida toma de postura, de reconocimiento del papel de los tribunales en el respeto efectivo de la tutela judicial efectiva y de plasmación concreta de un concepto de justicia material frente a concepciones ortodoxas del principio de separación de poderes que en casos como este acaso deban ceder. Además, puede decirse que encaja en el control efectivo de la actividad de la Administración y su sometimiento a los fines que la justifican, en el marco del art. 106 de la Constitución, respetando, diríamos, su espíritu.

Encontramos un claro precedente de esta línea jurisprudencial en las SSTS 2900 y 15769, de 28 de marzo de 1990 (ponente: Mariano de Oro Pulido López), en las que, recogiendo la doctrina sentada en la sentencia de la antigua Sala Cuarta de 27 de abril de 1983, se sostiene que «[...] cuando conste de manera cierta y convincente la incongruencia o discordancia de la solución elegida con la realidad a que se aplica, la jurisdicción contenciosa debe sustituir esa solución por la que resulte más adecuada a dicha realidad o hechos determinantes con el fin de evitar que se traspasen los límites racionales de la discrecionalidad y se convierta ésta en causa de decisiones desprovistas de justificación fáctica alguna» $\left(\mathrm{FJ} 3^{\circ}\right)$. Es decir, la solución técnica en que se concrete la discrecionalidad debe venir respaldada y justificada con los datos objetivos sobre los cuales se opera, por lo que que cuando conste de manera cierta y convincente la incongruencia o discordancia de la solución elegida con la realidad, la jurisdicción contenciosa tendrá capacidad para sustituir esa solución por la que resulte más adecuada a dicha realidad o hechos determinados. Ahora bien, como afirma la STS de 15 de marzo de 1993 (ponente: Javier Delgado Barrio):

Ya en el terreno de la sustitución de la calificación anulada por la pretendida por la parte en su día demandante — «zona residencial en manzana cerrada», clave

centro hospitalario transfronterizo que dependen de la nueva gestión de los nuevos sectores urbanizables al punto que por el crecimiento de nuevos residentes no cabe dilatar la resolución del caso cuando no caben los alumnos en los actuales centros públicos ni en los concertados». El Tribunal Supremo observa al respecto que «[...] es claro que, en el supuesto de autos, el objeto de la controversia, la conformidad a Derecho de la aprobación definitiva de un instrumento de planeamiento se incardina sin dificultad alguna dentro del ámbito propio de la jurisdicción contencioso-administrativa y que, por tanto, no ha habido abuso por exceso en el ejercicio de la jurisdicción propia de este orden». Se trata, sin duda, de una solución muy cuestionable ya que, como puede observarse sin dificultad, el tribunal de instancia ha entrado de lleno en el ámbito de la discrecionalidad y debió, en mi humilde opinión, anular sin más, dejando a la Administración competente el ejercicio de su arbitrio legítimo. 
I- será de recordar que el criterio jurisprudencial en materia de calificaciones urbanísticas - S. 2-4-1991 (RJ 1991/3278) — es el de que aun procediendo su anulación en sede jurisdiccional no siempre resulta viable que los Tribunales formulen una nueva calificación: A) Si son posibles varias soluciones, todas ellas lícitas y razonables, únicamente la Administración actuando su potestad discrecional de planeamiento podrá decidir al respecto. B) Por el contrario, los Tribunales habrán de señalar la nueva calificación si las líneas del planeamiento conducen a una solución que se impone ya por razones de coherencia —así, SS. 22 septiembre y 15 diciembre de 1986- Así lo reclama el principio de efectividad de la tutela judicial — art. 24,1 de la Constitución — que quedaría claramente burlado si los Tribunales, contando con datos suficientes, no resolvieran todo lo necesario en relación con las cuestiones planteadas en el proceso (FJ $\left.7^{\circ}\right)$.

Un ejemplo reciente de esta línea de garantía de lo que ahora se denomina una «buena administración de justicia», que implicará una efectiva y rápida tutela judicial, lo encontramos en la Sentencia 3272/2016, de 27 de junio, rec. 866/2014, en los siguientes términos (FJ 3o):

[...] la sentencia impugnada, no es que le atribuya la condición de suelo urbanizable invadiendo competencias que le son ajenas, sino que, más exactamente, lo que hace es deducir que dicha condición es la que corresponde otorgar a la zona de acuerdo con el planeamiento urbanístico preexistente; que es cosa bien distinta. [...] En la medida, por tanto, que la clasificación urbanística controvertida no es el resultado del ejercicio de una potestad administrativa que desde luego no le corresponde a la Sala de instancia sino que es debida a la consideración que dicha Sala deduce de la ordenación urbanística preexistente, en base a unas razones suficientemente atendibles, no cabe apreciar la existencia del vicio denunciado al amparo de este motivo de casación que estamos examinando en este apartado.

El estudio de la jurisprudencia, sin embargo, nos permite deducir que lo habitual será que la sentencia se limite a anular sin seńalar el régimen jurídico correcto. Así aconteció, por ejemplo, en la STS 1612/2010, de 25 de marzo, rec. 5635/2006. El TS considera que la Sala de instancia no incurrió en exceso de jurisdicción al anular la clasificación urbanística realizada por la Administración, en relación con un polémico complejo de ocio y turismo: la «Ciudad del Golf», que se pretendía desarrollar en Las Navas del Marqués (Ávila). En concreto, la Administración aprobó una revisión del planeamiento que clasificaba como suelo urbanizable delimitado suelos que estaban integrados en una zona de especial valor ecológico, clasificada como Zona de Especial Protección para las Aves y Lugar de Interés Comunitario. A su vez, se encontraban clasificados por las Normas Subsidiarias de Planeamiento de Las Navas del Marqués, del siguiente modo: 95 hectáreas como suelo no urbanizable de régimen normal, 
mientras que el resto del terreno como suelo no urbanizable especialmente protegido. Si bien, mediante la modificación puntual núm. 7 de tales NNSS, las citadas 95 hectáreas se clasifican como «suelo urbanizable delimitado». Finalmente con las NNUU municipales aprobadas con las resoluciones recurridas, la totalidad de los terrenos incluidos en el Sector SUZD-4 se clasifican como suelo urbanizable delimitado. El TSJ de Castilla y León anuló la clasificación realizada en la revisión del planeamiento. La anulación afectó a la totalidad del suelo, incluyendo las 95 hectáreas que en una revisión anterior se habían clasificado como suelo urbanizable delimitado pues cualquier revisión del planeamiento es una disposición reglamentaria susceptible de ser revisada, confirmándola o anulándola, sin perjuicio del régimen anterior. La Sala de instancia, en base a la doctrina jurisprudencial e interpretando la normativa relevante, llegó a la conclusión de que la clasificación de los terrenos comprendidos en el sector en cuestión como suelo urbanizable es incompatible con lo que se dispone en las normas autonómicas así como con la Ley estatal del suelo. La parte actora, sin embargo, no solo pretendía la anulación de tal clasificación, sino además que tales terrenos se clasificaran como «suelo no urbanizable con protección natural». El Tribunal de instancia rechazó esta pretensión en referencia al art. 71.2 de la LRJCA que prevé, como sabemos, que «los órganos jurisdiccionales no podrán determinar la forma en que han de quedar redactados los preceptos de una disposición general en sustitución de los que anularen ni podrán determinar el contenido discrecional de los actos anulados». La nueva clasificación a realizar de dichos terrenos, dice el TS, corresponde al Ayuntamiento de Las Navas del Marqués con la posterior aprobación de la Junta de Castilla y León, quienes en todo caso habrán de tener en cuenta los pronunciamientos de esta sentencia y los fundamentos de derecho en que se apoyan así como la normativa urbanística vigente y aplicable, concluye el TSJ de Castilla y León. El TS considera, en fin, como he avanzado antes, que no ha habido exceso o abuso de jurisdicción. En este caso, por tanto, se plantea con suficiente claridad la competencia de anulación del Tribunal, que no implicará el nacimiento de competencia jurisdiccional alguna para establecer un nuevo criterio.

\section{LA ANULACIÓN JUDICIAL DE UNA ALTERNATIVA QUE OBLIGA A LA ADMINISTRACIÓN A OPTAR POR LA RESTANTE NO IMPLICARÁ UNA INFRACCIÓN DE LAS NORMAS DE JURISDICCIÓN}

Tampoco se habrá considerado un abuso en el ejercicio de la jurisdicción la anulación judicial de una alternativa que obligue a la Administración optar por la restante. Nos encontramos ante un supuesto parecido al descrito en el tercer punto de este epígrafe, si bien en este caso el Tribunal se limita a anular. Es el caso planteado en la STS 4776/2012, de 5 de julio, rec. 2732/2009. 
Las Administraciones recurrentes, la Generalidad de Cataluña y el Ayuntamiento de Manresa, consideran que la sala de instancia incurrió en exceso de jurisdicción, infringiendo los artículos 106.1 de la Constitución, 8 de la Ley Orgánica del Poder Judicial y 71.2 LJCA porque, al haber anulado el sistema de actuación por expropiación, obligaba a establecer un sistema de actuación privado de reparcelación que, a su modo de ver, poco tiene que ver con el que la Administración había diseñado inicialmente y cuya elección se encontraba perfectamente detallada y justificada en la memoria de planeamiento. El TS rechaza las pretensiones de las recurrentes, en los siguientes términos:

[...] la Sala de instancia, al anular el sistema de expropiación establecido para la ejecución del ámbito, por considerar que no estaba justificada la elección de dicho sistema, no ha sustituido a la Administración sino que ha llevado a cabo un control de legalidad y no vincula en absoluto la elección de las demás alternativas de gestión que contempla la legislación urbanística; aunque cierto es que la Ley autonómica 2/2002 solo contempla como sistemas de actuación la expropiación y la reparcelación, si bien éste segundo presenta diversas modalidades (compensación básica, compensación por concertación, etc.).

Por tanto, no puede compartirse la idea de que la resolución de la Sala de instancia, al invalidar la determinación correspondiente a la elección del sistema de ejecución, haya incurrido en exceso en el ejercicio de la jurisdicción, pues se trata de un puro control de legalidad al que la Sala de instancia no ha anudado contenidos discrecionales en sustitución de las determinaciones invalidadas, habiéndose limitado a declarar la nulidad de la determinación que a su juicio no se acomodaba al ordenamiento jurídico ${ }^{19}$.

\section{6. ¿PUEDE EL TRIBUNAL ANULAR UNA DISPOSICIÓN CON LA INDICACIÓN DE QUE REVIVE LA DISPOSICIÓN PREEXISTENTE?}

En principio, tampoco parece que constituya un abuso en el ejercicio de la jurisdicción la anulación judicial de una disposición de un instrumento de planeamiento con la indicación de que revive la disposición vigente hasta que se dictó la disposición anulada. Sin embargo, de conformidad con lo estudiado hasta ahora, plantea dudas formales desde la perspectiva del precepto analizado, el art. 71.2 LJCA. Así, la STS 8472/2011, de 2 de diciembre, rec. 483/2008, apoyándose en la doctrina sentada en alguna sentencia previa, subrayará:

[...] la sentencia no ha realizado luego ninguna declaración que constituya intromisión alguna en el ejercicio de las potestades discrecionales que corresponde

19 Véase, en idénticos términos, la STS 4688/2012, de 28 de junio, rec. 2103/2009. 
al planificador urbanístico, ni desde luego ha determinado el contenido en el que ha de quedar redactada las normas que el plan contiene, pues las cosas han vuelto a su estado anterior, al haber recobrado vigencia la norma que había derogado el plan anulado. Y desde luego nada impide al planificador realizar los cambios de calificación que demande el interés general y que sean conformes con el ordenamiento jurídico.

En este sentido hemos declarado en sentencia de 29 de abril de 2011 (recurso de casación no 3625/2007) que la sentencia recurrida, en el ya citado fundamento quinto, se limita a señalar que como consecuencia de la anulación de la modificación puntual controvertida recuperaba su vigencia la ordenación anterior [...]. Pero la sentencia no condiciona ni prejuzga el ejercicio del ius variandi que en el futuro pueda hacer la Administración urbanística para volver a modificar aquella ordenación primigenia en el sentido que considere conveniente, dentro, claro está, de los límites legales que circunscriben el ejercicio de dicha potestad ${ }^{20}$.

El razonamiento es lógico y coherente. No parece que la indicación de que renace la disposición sustituida por la que se anula, suponga un exceso de jurisdicción, pues realmente es la consecuencia lógica de la anulación y, como indica el Tribunal, el ius variandi de la Administración permanece intacto, por lo que, en este caso concreto, en el marco de la ley, podría disponer plenamente de su potestad de planificación, como no puede ser de otra manera. Por ello, en la STS 2331/2016, de 18 de mayo, rec. 1763/2015, el Tribunal concluye que sí ha habido un exceso en el ejercicio de la jurisdicción, pues el tribunal de instancia anuló una disposición urbanística de un plan, con la indicación de que revivía, con carácter definitivo, el régimen anterior ( $\left.\mathrm{FJ} \mathrm{6} 6^{\mathrm{a}}\right)$ :

[...] cabe apreciar en la sentencia la extralimitación en el ejercicio de su propia potestad que es objeto de crítica por parte municipal, exceso que se concreta en el inciso contenido en el fallo con esta expresión: «...Y, como consecuencia de lo anterior, declarar nula también la desafectación de las parcelas municipales, ubicadas en la zona de Calafató, que habían sido incluidas en el Sector de autos. Parcelas, éstas, que recuperarán, con carácter definitivo, la clasificación y calificación que ostentaban tras la aprobación provisional del Plan citado anteriormente...». [...] la sentencia desborda sus posibilidades de enjuiciamiento del asunto, pues tal declaración no es meramente explicativa de los efectos de la nulidad — como pretende, en su escrito de oposición, la parte recurrida — sino que tiene un alcance ciertamente mayor, al menos con una triple consecuencia que parece que ni aun el Ayuntamiento que esgrime el motivo de casación parece

20 En el mismo sentido, las SSTS 2401/2011, de 29 de abril, rec. 3625/2007; 8445/2011, de 30 de noviembre, rec. 5617/2008; 5258/2013, de 24 de octubre, rec. 4544/2010. 
haber advertido: a) en primer lugar, se compromete la clasificación y calificación de las parcelas municipales ubicadas en la zona de Calafató, al preverse para ellas «...que recuperarán, con carácter definitivo, la clasificación y calificación que ostentaban tras la aprobación provisional del Plan citado anteriormente...", lo que significa que la vinculación que el fallo impone va mucho más allá de lo, en su caso, necesario, para dotar de efectos explicativos a la anulación, pues el carácter definitivo asignado, aunque parece fruto de la impremeditación, solo significa que queda privada sobre tales parcelas toda ulterior y posible modificación. b) En segundo término, no solo se impone la clasificación, y también la calificación — nociones ambas de innegable índole urbanísticasino que también se prohíbe de un modo permanente la desafectación de las parcelas, algo que ni siquiera constituye, en sí mismo, el ejercicio de una potestad urbanística ni discurre en el campo de la acción (pública) legalmente reconocida en esa materia, sino más bien en el título competencial de los bienes de las Corporaciones locales, pues cabría pensar, al menos de forma hipotética, en futuros actos de desafectación o disposición de esos mismos terrenos basadas en otros motivos distintos que la sentencia, consciente o no, parece impedir. c) Finalmente, cabe apreciar también que el mandato de la sentencia - es de repetir que aquí obra la Sala ex officio, pues ninguna de las partes le pidió tal determinación en el fallo, que además no es consecuencia de razonamiento previo alguno- lo es «que recuperarán, con carácter definitivo, la clasificación y calificación que ostentaban tras la aprobación provisional del Plan citado anteriormente...», lo que significa que, también al margen del debate procesal, se sitúa en esa fase del procedimiento de aprobación del POUM una especie de punto de retroacción que desmiente y enerva por completo el efecto de nulidad radical del plan, por ser una disposición de carácter general, insusceptible por ende de subsanación (arts. 62.2 y concordantes de la Ley 30/1992, de 26 de noviembre, de Régimen Jurídico de las Administraciones Públicas y del Procedimiento Administrativo Común). Dicho de otro modo, aun aceptando dialécticamente que la mención al destino de las parcelas municipales se limita sólo a una explicación o recordatorio de las consecuencias legales de la nulidad, el régimen de tales terrenos debía ser el determinado por el planeamiento anterior, en tanto éste recobra vigencia, no así el que fijaba el propio POUM anulado y carente de efecto alguno, por más que tal régimen de afectación, clasificación y calificación viniera determinado en la aprobación provisional, pues ésta también decae imperativamente por efecto legal. En suma, debemos casar la sentencia en cuanto al inciso final, que debe suprimirse, efecto éste que satisface al Ayuntamiento de La Ametlla de Mar en tanto en él se concreta la extralimitación jurisdiccional que se trata de conjurar.

Sin embargo, atendiendo, igualmente, a la jurisprudencia del TS, encontramos otra línea jurisprudencial en sentido contrario. Así, las Sentencias de 16 y 23 de enero, 14 de diciembre de 1998 y, más recientemente, la Sentencia de 29 de junio de 2016 (FJ 30), indican: 
[...] el poder de sustitución no puede llegar allí donde la ley reserva a la Administración un poder discrecional de decisión que responde a su específica posición político-constitucional. $\mathrm{O}$, dicho en otros términos, tal poder sólo alcanza hasta donde la ley regla la actividad administrativa que en el ámbito de la potestad reglamentaria no suele alcanzar hasta la imposición del contenido con que ha de quedar redactada la norma reglamentaria, aunque exista la obligación legal de dictarla.

La misma solución se ha adoptado en el ámbito del sector eléctrico. Ante la anulación de una disposición sobre el régimen retributivo de las instalaciones de producción de energía eléctrica a partir de fuentes renovables, en el marco del Real Decreto 413/2014, de 6 de junio, tampoco se habrá considerado que la anulación del nuevo régimen implique que reviva el anterior. Ello, sin duda, sería una intromisión judicial en el ámbito de la discrecionalidad de la política económica de la Administración, que debe contextualizarse en la crisis económica y financiera de los últimos años ${ }^{21}$. Así, en la sentencia 3097/2016, rec. 529/2014, el TS rechaza la aplicabilidad del art. 71.2 «en relación con el pedimento de la parte recurrente de restablecimiento del régimen primado anterior, pues la parte recurrente no solicita de la Sala una determinada redacción en sustitución de un precepto anulado, sino un pronunciamiento sobre el régimen retributivo aplicable en caso de que prospere su pretensión de anulación $»^{22}$.

\section{AUTONOMÍA LOCAL Y SUSTITUCIÓN JUDICIAL DE LA DISCRECIONALIDAD ADMINISTRATIVA}

El principio de autonomía local ha justificado, en ocasiones, la opción de los tribunales de instancia por dar preferencia a la aprobación municipal provisional de un instrumento urbanístico frente a su desestimación por el

21 El TC hace referencia a estas cuestiones en la Sentencia 270/2015, de 17 de diciembre: «En una situación de crisis económica generalizada, modificaciones análogas a la presente han sido llevadas a cabo en éste y en otros sectores económicos, que, además, están sometidos a una intervención administrativa más intensa, dada su incidencia en los intereses generales, como lo es la actividad de producción de energía eléctrica. Ello hace particularmente inviable la pretensión de que los elementos más favorables de su régimen económico estén investidos de una pretensión de permanencia e inalterabilidad en el tiempo, pues es precisamente la protección de esos intereses generales la premisa que obliga a los poderes públicos a adaptar su regulación al cambio de las circunstancias» (FJ 7oo).

En la misma línea en torno al mismo tema, la STS 2868/2016, de 20 de junio, rec. 428/2014 (FJ 6o). 
órgano autonómico competente. Con ello se eluden los criterios discrecionales por los que puede optar la comunidad autónoma y se desconoce el principio de coordinación que le corresponde a esta última Administración, como garante de una ordenación racional del territorio ${ }^{23}$. Es el caso planteado en la STS 3414/2013, de 6 de julio, rec. 4284/2010, comentada anteriormente, y en la sentencia en la que me basaré para ejemplificar este punto. Me refiero a la Sentencia 1562/2013, de 26 de marzo, rec. 4312/2009 (ponente: Jesús Ernesto Peces Morate). Se trata del recurso de casación presentado por la Generalidad de Cataluña contra la sentencia del TSJ de Cataluña, de 13 de junio de 2008, estimatoria del recurso presentado por la Sociedad Limitada Wiltord Promodesarrollo contra la desestimación, por acto presunto del recurso de alzada, de la aprobación de la Modificación Puntual del Plan General de Ordenación Urbana de Sant Iscle de Vallalta.

La sentencia de instancia no solo anula la resolución de denegación de la aprobación de la modificación del plan, sino que ordena su aprobación definitiva, sustituyendo, por tanto, la discrecionalidad de la Administración autonómica en la toma de esta decisión. Los motivos por los que la Generalidad rechazó el recurso contra la desestimación presunta de la aprobación puntual del plan, recogidos en el antecedente de hecho $2^{\circ}$, son los siguientes:

[... 1 . No se justifica la necesidad de un nuevo sector de suelo urbano dada la reserva suficiente de suelo urbanizable por desarrollar. 2. La posición del sector en situación discontinua con el núcleo urbano de Sant Iscle de Vallalta, formando una isla de 5 ha de suelo urbanizable envuelto de suelo no urbanizable, contradice el principio de desarrollo urbanístico sostenible, previsto en el artículo 3 de la Ley 2/2002, de 14 de marzo, de Urbanismo, ya que propone un modelo que potencia la dispersión en el territorio. 3. Los terrenos objeto de la modificación: 1. En atención a las directrices establecidas en el artículo 9 de la Ley 2/2002, de 14 de marzo, de Urbanismo, los citados terrenos se consideran totalmente inadecuados para su transformación urbanística, dado que tienen una pendiente de entre un $35 \%$ y un $50 \%$; 2. El bosque existente ocupa el $40 \%$ de la superficie del sector, concentrándose en el perímetro del ámbito de continuidad con la masa boscosa del entorno, hecho que comporta un riesgo para las personas en caso de incendio forestal, contradiciendo el artículo 9.2 de la Ley 2/2002, de 14 de marzo. 4. La creación de un nuevo sector de suelo urbanizable sin que se considere justificado el interés general de la propuesta dado que las obras de urbanización externas al sector son necesarias, no se considera adecuado dado que la magnitud de la propuesta, de 5 ha y 120 viviendas, comporta en un municipio de las características de Sant Iscle de Vallalta, con una población

23 Sobre este tema, véase O. Bouazza Ariño (2010), «Principio de coordinación», en J. A. Santamaría Pastor (dir.), Los principios jurídicos del Derecho Administrativo, Madrid: La Ley, págs. 921-944. 
de 944 personas según el censo de 2001 y de 1016 habitantes según el padrón de 2004, una previsión de población que cubre una demanda superior a 16 años de crecimiento absoluto de los habitantes del municipio.

El tribunal de instancia estimó el recurso ya que el nuevo desarrollo planteado por la modificación puntual atendía a un modelo de desarrollo urbanístico local, por lo que, a su modo de ver, debe prevalecer el criterio municipal, a pesar de la referencia que hace la Generalidad a la necesidad de contener la dispersión territorial y favorecer un desarrollo urbanístico sostenible, de conformidad con la Ley autonómica de urbanismo.

La Generalidad interpone un recurso de casación ante el TS alegando —aparte de la infracción de normas estatales, que considera relevantes y determinantes del fallo, extremo en el que se estima el recurso- un abuso por exceso en el ejercicio de la jurisdicción. La Sala de instancia, a juicio de la Administración recurrente, asumió funciones que corresponden a la Administración, lo que supone una infracción de los artículos 106.1 de la Constitución, 8 de la Ley Orgánica del Poder Judicial y 71.2 de la Ley de la Jurisdicción Contencioso Administrativa, así como de la jurisprudencia que los interpreta. Esta infracción se ha producido, en opinión de la Generalidad, porque la sentencia no se limita a anular el acuerdo impugnado, sino que, al propio tiempo, ordena la aprobación definitiva de la modificación del Plan elaborada por el municipio, con lo que se ha privado a la Administración autonómica de llevar a cabo los demás controles de legalidad sobre los que no se pronuncia la sentencia como, por ejemplo, en relación con la evaluación de impacto ambiental.

El TS resuelve la controversia a este respecto en el FJ $1^{\circ}$. No observa que haya habido abuso en el ejercicio de la jurisdicción. Indica el Alto Tribunal que la sentencia de instancia restringió su análisis a uno solo de los problemas suscitados, el relativo al alcance de la modificación sobre los intereses locales, entendiendo que afectaba a «un aspecto discrecional de ámbito estrictamente local» y no dio ninguna respuesta al resto de las cuestiones suscitadas por la representación procesal de la Administración autonómica denunciada, entre ellas, las concernientes a los riesgos por incendios o a la necesidad de realizar la previa evaluación de impacto ambiental. Ahora bien, como la sentencia no se pronuncia sobre los extremos indicados, la Administración autonómica debió invocar, dice el TS, como motivo casacional, la infracción de las normas reguladoras de la sentencia, por adolecer de incongruencia omisiva, sin que esa omisión pueda ser entendida como un desapoderamiento del órgano urbanístico decisorio. Antes de ofrecer estas dos argumentaciones, el TS dará por buena la prevalencia que otorga el tribunal de instancia al principio de la autonomía local frente a otros como el de coordinación, que legítimamente corresponde a la comunidad autónoma en virtud de la necesaria toma en 
consideración de cuestiones que escapan del ámbito local ${ }^{24}$. Y que tanta trascendencia adquiere en el ámbito del urbanismo y de la ordenación del territorio, ámbitos de especialización en los que está mejor situada la Administración que los jueces y tribunales, como indicó el profesor Lorenzo Martín-Retortillo en el comentario a los avatares del artículo $106 \mathrm{CE}$, antes referido.

En cualquier caso, el TS reconoce el derecho de la Administración local a establecer una determinada clasificación y ordenación y a que sea aprobada por el órgano competente de la comunidad autónoma según la propuesta formulada, esto es, la aprobada provisionalmente. La declaración de ese derecho, a modo de ver del TS en casación, es expresión genuina y funcionalmente correcta del control de la legalidad cuando se aprecia la vulneración del principio de autonomía local. Solución más que discutible, pues en verdad la autonomía local no debe desconocer en ningún caso los ámbitos legítimos de coordinación que deben realizarse desde ámbitos supralocales, en este caso, autonómicos, en garantía de intereses supramunicipales cuya protección escapa a las competencias locales.

En definitiva, se niega que haya existido sustitución judicial, con lo que no sería aplicable el artículo 71.2 en relación con el 88.1.a) de la anterior regulación de la LJCA. Se ha dado primacía al principio de autonomía local, bien que los intereses locales que sirven de fundamento al tribunal de instancia no han quedado acreditados y quedan desacreditados por el propio TS al resolver el segundo motivo en el que se funda el recurso, como se verá a continuación, frente a la sustitución que ha hecho el tribunal de instancia de la decisión presunta de la Administración autonómica.

En mi humilde opinión, en primer lugar debe reprocharse, como no puede ser de otra manera, que la Administración autonómica competente resolviera el proceso de modificación del plan con un silencio. En este caso, el silencio impidió obtener una resolución razonada del porqué se consideraba que el modelo de desarrollo municipal no se daba por bueno desde la perspectiva global de la ordenación supramunicipal en materia de control de la urbanización. Por ello, la Administración autonómica debió dictar resolución expresa, como bien indica la Ley de Procedimiento Administrativo. Hecha la crítica al silencio producido en este caso, el Tribunal, como no se limita a anular, sino que ordena a la Administración demandada la aprobación definitiva de la Modificación puntual del Plan General de Ordenación Municipal de Sant Iscle de Vallalta, en la forma recogida en la aprobación provisional por la corporación local, ha sustituido la legítima discrecionalidad que corresponde

24 Sobre el justo equilibrio entre los diferentes intereses en conflicto, debe citarse el libro de J. M. Rodríguez de Santiago (2000), La ponderación de bienes e intereses en el Derecho Administrativo, Madrid: Marcial Pons. 
a la Administración en un tema tan complejo como es el de la ordenación del territorio. En efecto, no solo se ha limitado a anular una decisión, sino que ha indicado la opción local en contra del criterio autonómico prevalente, por lo que sí ha habido una infracción de las normas referidas a la jurisdicción pues, a mi modo de ver, ha optado por una solución que rechazó la Administración competente en el ejercicio legítimo de su discrecionalidad.

\section{8. ¿PUEDE EL TRIBUNAL CONTROLAR LAS OMISIONES REGLAMENTARIAS?}

En el tira y afloja entre el principio de separación de poderes, el derecho a una buena administración y el derecho a una buena administración de justicia, nos podemos plantear si el Tribunal puede sustituir la inactividad o la omisión reglamentaria. Recordemos que en el iter parlamentario de la LJCA, en la tramitación del artículo 104 del Anteproyecto de Constitución (actual artículo $106 \mathrm{CE}$ ), el Grupo Parlamentario Socialista del Congreso propuso una enmienda, según la cual se contemplaba parcialmente este supuesto en su segundo párrafo: «2. Los Tribunales controlarán la sumisión de la Administración a la Ley y al Derecho y el servicio a los fines que justifican su actuación, declaran las responsabilidades patrimoniales por las lesiones injustas que su actividad ocasione a los ciudadanos y suplen la omisión de actividad de la Administración cuando tal actividad es legalmente obligada». El Tribunal Supremo ha llegado a una solución muy aproximada, que ha expuesto en varias sentencias, concluyendo que la ilegalidad omisiva será controlable por los tribunales cuando determine la creación de una situación contraria a la Constitución o al ordenamiento jurídico. Así, por ejemplo, la STS 6137/2013, de 5 de diciembre, rec. 5886/2009, FJ 8º, en referencia a la Sentencia de 28 de junio de 2004 recaída en el recurso contencioso administrativo 74/2002:

Las pretensiones deducidas frente a la omisión reglamentaria han encontrado tradicionalmente en nuestra jurisprudencia, además de la barrera de la legitimación, un doble obstáculo: el carácter revisor de la jurisdicción y la consideración de la potestad reglamentaria como facultad político-normativa de ejercicio discrecional. [...] Ahora bien, tales reparos no han sido óbice para que, ya desde antiguo, se haya abierto paso una corriente jurisprudencial que ha admitido el control judicial de la inactividad u omisión reglamentaria. En el ejercicio de esta potestad son diferenciables aspectos reglados y discrecionales (cfr. SSTS 8 de mayo de 1985, 21 y 25 de febrero y 10 de mayo de 1994), y no es rechazable ad limine, sin desnaturalizar la función jurisdiccional, una pretensión de condena a la Administración a elaborar y promulgar una disposición reglamentaria o que ésta tenga un determinado contenido, porque el pronunciamiento judicial, en todo caso de fondo, dependerá de la efectiva existencia de una obligación o deber legal de dictar una norma de dicho carácter en un determinado 
sentido. En el bien entendido de que únicamente es apreciable una ilegalidad omisiva controlable en sede jurisdiccional cuando el silencio del Reglamento determina la implícita creación de una situación jurídica contraria a la Constitución o al ordenamiento jurídico o, al menos, cuando siendo competente el órgano titular de la potestad reglamentaria para regular la materia de que se trata, la ausencia de la previsión reglamentaria supone el incumplimiento de una obligación legal establecida por la Ley o la Directiva que el Reglamento trata de desarrollar y ejecutar o de transponer. [...] Por otra parte, es éste un problema sustantivo diferenciable del alcance del control judicial, pues constatado el deber legal de dictar una regulación por la Administración y el incumplimiento de aquél resulta ciertamente más difícil admitir la posibilidad de una sustitución judicial de la inactividad o de la omisión administrativa reglamentaria hasta el punto de que el Tribunal dé un determinado contenido al reglamento omitido o al precepto reglamentario que incurre en infracción omisiva, siendo significativo a este respecto el artículo 71.2 de la nueva Ley de la Jurisdicción Contencioso-administrativa [...] Por consiguiente, la doctrina de esta Sala es, sin duda, restrictiva en relación con el control de las omisiones reglamentarias, tanto desde el punto de vista formal de su acceso a la jurisdicción como desde el punto de vista material o sustantivo, referido al contenido y alcance que corresponde a la función revisora del Tribunal. [...] En definitiva, como se ha dicho anteriormente, únicamente cabe apreciar una ilegalidad omisiva controlable jurisdiccionalmente, cuando, siendo competente el órgano titular de la potestad reglamentaria para regular la materia de que se trata, la ausencia de previsión reglamentaria supone el incumplimiento de una obligación expresamente establecida por la Ley que se trata de desarrollar o ejecutar, o cuando el silencio del Reglamento determine la creación implícita de una situación jurídica contraria a la Constitución o al ordenamiento jurídico. Aunque, en ocasiones, para la omisión reglamentaria relativa, el restablecimiento de la supremacía de la Constitución o de la Ley, pueda consistir en negar simplemente eficacia jurídica al efecto derivado de dicho silencio del reglamento contrario al ordenamiento jurídico (cfr. SSTS 16 y 23 de enero de 1998, 14 de diciembre de 1998 y 7 de diciembre de 2002 ).

En este caso, por consiguiente, se observa de manera clara y nítida la opción por un derecho a una buena administración y el control efectivo e incluso coadyuvante por parte del poder judicial en defensa del interés general cuando la Administración no actúa y, fruto de ello, se da una situación contraria a la Constitución o al ordenamiento jurídico.

\section{EL ARTíCULO 71.2 ES APLICABLE —-TAMBIÉN_ EN EJECUCIÓN DE SENTENCIA}

La prohibición general del artículo 71.2 LJCA no solo será aplicable al dictar la sentencia, sino también al ejecutarla. El derecho a la tutela judicial 
efectiva, como ha dicho el Tribunal Constitucional reiteradamente, incluye el derecho a la ejecución de la sentencia. Este a su vez comprende, como parte integrante de su contenido, la garantía de una interpretación finalista del fallo, infiriendo de él todas sus naturales consecuencias (véanse, por ejemplo, las SSTC 25/1987, 92/1988 y 148/1989). Y también la garantía de agotamiento del procedimiento incidental de ejecución, evitando con ello la carga injustificada de nuevos procesos (por ejemplo, la STC 167/1987), con lo que la ejecución de una sentencia requerirá actuaciones adicionales a su publicación en el boletín oficial correspondiente del fallo de la sentencia de anulación. Será necesario llevar a cabo, con el carácter de incidentes de la ejecución, todas las cuestiones directamente relacionadas con la efectividad del fallo, dirigidas al restablecimiento de la legalidad quebrantada por causa de las infracciones que determinaron su nulidad. Solo cuando este derecho se haya hecho realidad o, por el contrario, cuando se hayan controlado en el mismo proceso de ejecución los eventuales obstáculos, materiales o jurídicos, que puedan surgir para la efectividad de tal derecho, podrá afirmarse que la ejecución está agotada (al respecto, véase la STS de 11 de julio de 2006, dictada en el recurso de casación 7466/2004). Se requiere, por tanto, una diligente actividad judicial más intensa que precise, analizando todas las circunstancias concurrentes, en qué medida se puede restablecer la realidad anterior a la modificación anulada, adoptando las medidas adecuadas para el logro de tal fin (STS 868/2016, de 2 de marzo, rec. 1626/2015). A sensu contrario, esto significa que el tribunal no podrá ir más allá. No podrá practicar actuaciones que no sean estrictamente necesarias para la ejecución de lo declarado en la sentencia, pues ello podría afectar al ámbito de la discrecionalidad administrativa en relación con el asunto decidido ${ }^{25}$.

\section{FINAL}

El contenido discrecional de los actos administrativos supone varias soluciones, todas ellas válidas en el marco de la ley. Optar por cualquiera de ellas es una función típicamente administrativa, no jurisdiccional. Una vez se ha estimado un recurso y se ha anulado el acto impugnado, el tribunal no podrá determinar la solución que considere más conforme a derecho. En caso

25 Sobre este tema, es ineludible la consulta de los trabajos de M. Beltrán de Felipe (1995), El poder de sustitución en la ejecución de las sentencias condenatorias de la Administración, Madrid: Civitas; e I. Martín Delgado (2006), Función jurisdiccional y ejecución de sentencias en lo contencioso-administrativo, Madrid: Marcial Pons. 
contrario, nos encontramos ante una invasión de la función administrativa, en el ejercicio de la discrecionalidad que la ley ofrece a la Administración y no por ello al juez.

En el tema de la discrecionalidad administrativa hay que tener en cuenta que el legislador no ha predeterminado una solución sino que abre el abanico para que la Administración, en base a criterios de oportunidad, económicos, sociales, ambientales, etc., elija entre un abanico de soluciones posibles. Es el propio legislador el que permite optar a la Administración. La ley renuncia a predeterminar un contenido y atribuye una labor de integración al órgano administrativo. Por ello, como la discrecionalidad se permite y se habilita por el legislador, con la finalidad de que la Administración escoja en base a diferentes criterios, que atiende a razones de política más bien programática, siempre que se respete el fin de la ley y el criterio de la competencia, no será lícito que el juez, tras anular un acto discrecional, se incline por otra de las soluciones posibles. Todo ello excepto en el caso de que la discrecionalidad desaparezca tras la anulación del acto discrecional, restando pues una única solución, o bien si se sobrepasan los límites de los actos discrecionales, en cuyo caso no nos encontraríamos realmente ante la discrecionalidad, sino ante la arbitrariedad. Así, por ejemplo, la Administración no podría clasificar suelo como urbanizable si de la realidad fáctica y normativa se desprende que el suelo es no urbanizable de especial protección. En caso de infracción, el juez podría determinar la clasificación correspondiente, pues parece que no hay margen de discreción y el juez tampoco es un mero espectador, sino que tiene como misión constitucional controlar que la Administración sirve al fin que la justifica que es siempre un fin de interés general (art. $103 \mathrm{CE}$ ).

Habrá que determinar en cada caso, por consiguiente, el ámbito de la discrecionalidad concedido por la ley al órgano administrativo. A partir de ahí podrá determinarse el papel del juez y, sobre todo, hasta dónde llega su poder de fiscalización, más allá del cual nos encontramos ante una infracción de las normas referidas a la jurisdicción o, lo que se ha denominado hasta ahora, un abuso o exceso en el ejercicio de la jurisdicción, que puede constituir el fundamento del recurso de casación.

El juez, en fin, no puede configurarse como un estrato jerárquicamente superior con poder de sustitución de las decisiones de la Administración en la gestión de los intereses públicos que la ley le confía, esto es, que la ley le ofrece para optar según criterios de oportunidad o conveniencia no predeterminados deliberadamente por la ley. La misión del juez será la de corregir las extralimitaciones de la actuación de la Administración, infringiendo el ordenamiento jurídico. No encaja en el ámbito de actuación judicial la revisión de los criterios de oportunidad que ha adoptado la Administración en el marco que le permite la ley. El juez, en fin, no debe irrumpir en el ámbito que la ley 
ofrece a la Administración, sin más, salvo que esta haya actuado de una manera disconforme a derecho, no haya subsumido correctamente el supuesto de hecho producido en la realidad en el supuesto de la norma o no haya atendido a los fines que la justifican, en cuyo caso entraría la labor de control del juez de revisión de la actuación de la Administración. 
